\title{
Characterization of a resistance-breaking BaYMV isolate from Belgium
}

\author{
S Steyer ${ }^{1 *}, \mathrm{~J} \mathrm{Kummert}^{2}$, F Froidmont ${ }^{3}$ \\ ${ }^{1}$ CRA, station de phytopathologie, chemin de Livoux: \\ 2 IRSIA, centre de phytovirologie, unité de pathologie, UER de phytopathologie, faculté des sciences agronomiques, \\ av Maréchal-Juin, 13: \\ ${ }^{3}$ CRA, station d'amélioration des plantes, rue du Bordia, 4, B-5030 Gembloux, Belgique
}

(Received 20 May 1995; accepted 4 July 1995)

\begin{abstract}
Summary - A field near Huccorgne, in the province of Liège, Belgium, sown with the winter barley cultivar Express, has been showing slight mosaic symptoms since 1990. As the symptoms were attributed to an infection by barley yellow mosaic virus, experimental plots for an evaluation of the resistance of barley breeding material were established there from 1991 onwards. Symptoms were scored by visual assessment on a range of cultivars including old French varieties, some resistant Japanese material and breeding material from the Plant Breeding Station, Gembloux. The results were compared with those obtained for the same material sown in a field infected with the common BaYMV and BaMMV isolates. The differences in the behavior of some cultivars or lines in the 2 fields were due to the emergence of a virus strain, which, at present, is limited to this particular field. The use of molecular-based detection techniques and partial sequencing have shown that the new viral agent characterized at Huccorgne is a strain of BaYMV.
\end{abstract}

\section{barley / BaYMV / BaYMV2 / visual assessment / breeding}

Résumé - Caractérisation en Belgique d'un isolat du virus de la mosaïque jaune de l'orge surmontant la résistance de l'hôte. En Belgique, un champ d'orge, situé près de Huccorgne, dans la province de Liège et emblavé avec le cultivar Express, montre des symptômes légers de mosaïque depuis 1990. Comme ces symptômes ont été attribués à une infection de la mosaïque jaune de l'orge, des parcelles expérimentales y ont été mises en place depuis 1991 en vue d'évaluer la résistance des orges sélectionnées vis-à-vis de cet isolat. Les symptômes visuels observés sur les différents cultivars mis en place dans cette parcelle sont notés et les résultats obtenus sont comparés à ceux obtenus pour le même matériel semé dans un champ d'essai où les souches communes de BaYMV et de BaMMV sont présentes. Les différences de comportement de certains cultivars ou lignées entre ces 2 champs sont dues à l'apparition d'un isolat particulier du virus actuellement limitée à ce seul champ. L'utilisation des techniques de détection basées sur les séquences d'acides nucléiques et le séquençage partiel ont montré que le nouvel agent viral caractérisé à Huccorgne est une souche du BaYMV.

orge / BaYMV / BaYMV2 / cotation visuelle / amélioration

\footnotetext{
${ }^{*}$ Correspondence and reprints
} 


\section{INTRODUCTION}

Yellow mosaic disease of winter barley is widespread in the cereal-growing areas of Belgium. It is recognized that the disease is caused by at least 2 viruses: barley yellow mosaic virus (BaYMV) and barley mild mosaic virus (BaMMV). These viruses have identical particle sizes and morphology, consisting of flexuous rods. They are soil-borne viruses, transmitted by the plasmodiophoraceous fungus Polymyxa graminis Ledingham. BaMMV is readily transmitted mechanically and occurs in plants in mixed infection with BaYMV, which is serologically distinct and poorly transmitted mechanically. During the crop season, the proportion of the 2 viruses varies in the plants: BaYMV appears preferentially during winter or at the beginning of spring; later in the season, the rise in temperature favors the development of BaMMV (Adams et al, 1987). In May-June, when the mean temperature rises above $15^{\circ} \mathrm{C}$, disease symptoms are no longer apparent on the young leaves.

In the fields, the presence of the viruses is evident in the typically irregular patches of paler green or yellow plants in the crop in late winter. Individual plants show longitudinal chlorotic streaks of varying size running along the veins. The streaks are more distinct on the younger leaves and can, in the most susceptible cultivars, turn yellowish-orange accompanied by a rapid death of the older leaves (Friedt, 1983).

The most spectacular damage occurs when the infected plants are submitted to frost without snow protection because of the great sensitivity of the diseased plants. A susceptible barley variety will generally have a more or less normal height with the yield reduced by only $15 \%$, but if similarly diseased plants are exposed to frost, the yield may be less than $50 \%$ of that of a resistant variety (Froidmont et al, 1993).

Trials using various control measures, including fungicide applications, delayed sowing and differences arising from the rate and the timing of nitrogen fertilizer applications have been reported in the literature. However, due to the transmission by soil fungus, the only practical means of controlling the disease is to use resistant cultivars (Adams et al, 1993).

In Belgium, where BaYMV and BaMMV always occur together in the fields, the conventional plant breeding program carried out by the Plant Breeding Station since the 1980s has produced several resistant barley cultivars with interesting agronomic traits. However, the major resistant winter barley cultivars which have been selected possess the same recessive resistance gene (designated as $y m$ 4) located on the long arm of chromosome 3 (Kaiser and Friedt, 1992). This gene is probably derived from the Yugoslav cultivar Ragusa and has been introduced into all BaYMV-resistant varieties in Europe (Götz and Friedt, 1993)

In 1988, in both Great Britain and Germany, symptoms similar to those induced by BaYMV were detected in some fields of BaYMV-resistant winter barley cultivars (Adams, 1991; Hoth, 1989). In Belgium, a field near Huccorgne sown with the BaYMV-resistant cultivar Express also showed slight mosaic symptoms in 1990 and in subsequent years. To our knowledge, this resistance-breaking BaYMV isolate is present only in this particular field, which is on embanked ground and where barley is sown every year because of the weak lift of the soil. In this field, the yield is reduced by only 10 quintals/ha, compared with neighboring fields on better soils and in the absence of this particular virus isolate (Froidmont et al, 1993). The identity of the resistance-breaking strain or isolate was not clear as it was not serologically detected with existing polyclonal and monoclonal antibodies routinely used for BaYMV and BaMMV detection.

Although the symptoms were milder than those observed after BaYMV and BaMMV infection on susceptible cultivars, they were similar to those caused by barley yellow mosaic, and so experimental plots for an evaluation of the resistance of barley breeding material were established in this field from 1991 onwards.

\section{MATERIALS AND METHODS}

In Gembloux and Huccorgne, the infected fields were sown early in the season to promote a regular emergence of the symptoms. The selection was made in these homogeneous infected soils (the homogeneity was controlled by sowing a susceptible variety such as Arton). The plots for the cultivars, lines or varieties under study consisted of two $1 \mathrm{~m}$ rows.

The plots were examined for symptoms at approximately monthly intervals from January to May and virus incidence was determined by examining each plant individually on at least 2 occasions each year and assessing the proportion of plants with symptoms to discriminate resistant and susceptible cultivars.

Some samples were analyzed by the direct sandwich ELISA test, using monoclonal antibodies raised against BaYMV obtained in Gembloux and polyclonal antibodies from Loewe directed against BaMMV. 


\section{RESULTS}

During the 1990-1991 crop season, a collection of selected cultivars was sown in Huccorgne and Gembloux. Table I summarizes the results of the observations conducted in these 2 fields. In Gembloux, for the cultivars or lines on which ELISA tests had been performed, a good correlation was observed between the presence of mosaic symptoms and a positive response to

Table I. Susceptibility or resistance of different barley cultivars during the 1990-1991 crop season in Huccorgne and Gembloux, Belgium.

Huccorgne

Express

Asorbia

Ou 4

Jochiwon covered

Pohang covered

Mushinchiang 3

Shahr-kord 1

Turkey 60

Turkey 524

28.28

Gaulois

Birgit

Franka

Regia

Diana

Sonate

Bison

Waveney

Torrent

Mélusine

Target

Comanche

Altaïr

Elara

Rebelle

H 010

$\mathrm{H} 011$

L 541

L 550

L 589-2

L 604-1

L 763

L 799

L 836-1

Comte de Serres

Hâtif de Grignon

Tourettes

lle de Ré

Mosar

Marne

Esc de Champagne

Escourgeon nouveau

Classica

Harfe

Arton
(S)

$S$

$\mathrm{S}$

R

R

$S$

$\mathrm{S}$

$\mathrm{S}$

$\mathrm{R}$

$S$

$\mathrm{S}$

(S)

(S)

(S)

$\mathrm{S}$

(S)

(S)

$S$

S

S

S

(S)

$\mathrm{S}$

R

$\mathrm{S}$

$\mathrm{S}$

$\mathrm{S}$

(S)

$\mathrm{S}$

S

R

(S)

(S)

$\mathrm{S}$

$\mathrm{S}$

R

$\mathrm{S}$

$\mathrm{S}$

S

$\mathrm{S}$
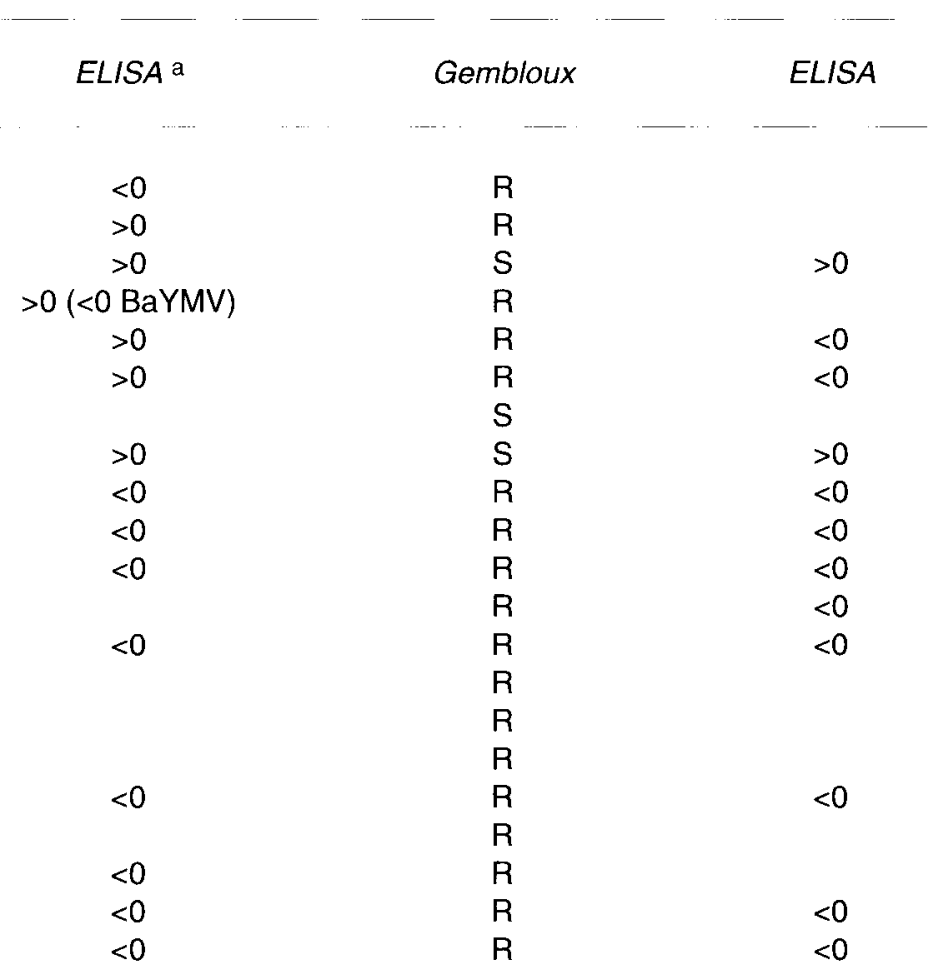

$\begin{array}{ll}R & \\ R & >0 \\ S & \\ R & <0 \\ R & <0 \\ R & \\ S & >0 \\ S & <0 \\ R & <0 \\ R & <0 \\ R & <0 \\ R & <0 \\ R & \end{array}$

R

R

R

$\mathrm{R}<0$

$<0$

$<0$

$<0$

$<0$

$R$

R

R

$\mathrm{R}$

$\mathrm{R}$

$<0$

$<0$

$\mathrm{R}$

$x^{2}$

R

R

R

$<0 \quad \mathrm{R}$

$<0 \quad \mathrm{R}$

$>0 \quad \mathrm{R}$

$\begin{array}{ll}<0 & S \\ R\end{array}$

$>0 \quad \mathrm{R}<0$

$>0 \quad \mathrm{~S} \quad>0$

R

R

S $>0$

$S=$ susceptible; $R=$ resistant; $(S)=$ cultivars which expressed milder symptoms than those observed with the common BaYMV or BaMMV strains. a BaYMV and BaMMV antisera. 
ELISA and vice versa. In Huccorgne, however, where many more cultivars or lines showed mosaic symptoms, we could distinguish between plants susceptible only to the new virus isolate present in this particular field (mosaic symptoms and negative ELISA tests) and others infected by $B a Y M V$ and BaMMV in the presence of the new isolate (mosaic symptoms and positive ELISA), although the same lines or cultivars did not show symptoms or react to BaYMV and/or BaMMV antisera in Gembloux.

In 1991-1992, F1 crosses of some varieties were sown. The varieties carried different resistance genes: $y m 4 ; y m 5$, which controls the resistance-breaking strain (table II); or the dominant allele $Y m$, which induces susceptibility.

Table III presents the results of the observations conducted in these 2 fields. We observed

Table II. Origin of the barley yellow mosaic resistance genes.

Gene

$y m 4$

$y m 5$
Controlled strain

BaMMV and BaYMV

BaMMV, BaYMV and BaYMV-2

Variety
Franka
Birgit
Athene
Regia
Old French varieties
Superchampenois
Comte-de-Serres
Marne
Île-de-Ré

Table III. Scoring scale for resistance to BaYMV in Gembloux and Huccorgne, Belgium in 1991-1992.

Variety

Superchampenois

Mushinchiang 3

Pohang covered

Jochiwon covered

Ou 4

Express

Arton

Galion

Ambio

Barbo

28.28

L 541

Esc-de-Champagne

Île-de-Ré

Marne

Comte-de-Serres

Anson

Crosses

Comte-de-Serres x 4612.61

Marne $x$ Plaisant

Comte-de-Serres $x$ Nordic

Express X L 541

Express $x$ Marne
Huccorgne

Gembloux

$\begin{array}{cc}R & \\ R & R \\ S & S \\ R & R \\ S & S \\ S & R \\ S(E L I S A>0) & S \text { (ELISA }>0) \\ S & R \\ S & S \\ R & R \\ S & R \\ R & R \\ R & R \\ R & R \\ R & R \\ R & R \\ R & R \\ & \\ S & \\ S & \\ R & \\ R & \\ R & \end{array}$


that: the crosses with Plaisant or 4612.61, carrying the gene $Y m$, produced $F 1$ populations susceptible to the common strains of BaYMV (present in Gembloux); and Comte de Serres (ym 5) x Nordic $(y m$ 4) or Marne $(y m 5) \times$ Express $(y m 4)$ produced $\mathrm{F} 1$ populations resistant to common BaYMV isolate and to the new strain.

From these observations, we can conclude that there are multiple allele in which the genes have the following dominance range: $Y m$ domi- nant, inducing susceptibility to the different types of virus; $y m 5$ intermediate, inducing resistance to $\mathrm{BaYMV}$ and $\mathrm{BaYMV}$; and $y m 4$ recessive, inducing resistance to BaYMV.

During the 1992-1993 and 1994-1995 crop seasons, some varieties were sown in Huccorgne and were scored visually for their behavior in the presence of the BaYMV resistance-breaking strain (table IV). (The 1993-1994 crop season was excluded because of a change in the field ownership.)

Table IV. Results of observations made in Gembloux and Huccorgne, Belgium during the 1992-1993 and 1994-1995 crop seasons.

1992-1993

Huccorgne

R

$\mathrm{R}$

$\mathrm{R}$

$\mathrm{R}$

$\mathrm{R}$

$\mathrm{R}$

$\mathrm{R}$

$\mathrm{R}$

$\mathrm{R}$

$\mathrm{R}$

$\mathrm{S}$

$S$

$S$

$S$

$S$

$\mathrm{R}$

$S$

Express

Mokusekko 3

Asahi 5

Akaji Nijo

Ouiita Nejire

Coll Coop Int 26 to 40

Gulz 3508.4

Gulz 3509.9

EA 52

W 9339-5026.1.5

Russia 57

Taranoo Sai

Komeirazu

Kearney

Nordic $\times$ Comte-de-Serres

Express x L 541

Express $x$ Marne

Express $x$ Mushinchiang

Express $x$ Kabinkataki
1994-1995

Huccorgne Gembloux

S = susceptible $; R=$ resistant 


\section{CONCLUSION}

All the differences observed between the behavior of the different barley cultivars, lines or crosses in Gembloux and Huccorgne, some examined by ELISA, confirm the emergence of a resistancebreaking strain of BaYMV in Huccorgne. Molecular biological analysis has proved that the coat protein gene of this strain has the same size and shares, respectively, 99.1 and $96.0 \%$ of homology at the nucleotide level, and 99.3 and $97.3 \%$ of homology at the amino acid level, with BaYMV-G (Peerenboom et al, 1992) and BaYMV$J$ (Kashiwazaki et al, 1989). This confirms that the resistance-breaking isolate present at Huccorgne is a BaYMV isolate (Kummert et al, submitted for publication). As for BaYMV-2, a resistance-breaking isolate of BaYMV described in Germany (Bendiek et al, 1993), only 2 amino acids are different for this isolate, compared with BaYMV-G.

The resistance-breaking strain present in Huccorgne corresponds to BaYMV. It seems, however, to differ from the resistance-breaking strains already described in Germany and France, and thus requires further characterization.

\section{REFERENCES}

Adams MJ, Swaby AG, Jones P (1987) Occurrence of 2 strains of barley yellow mosaic virus in England. Plant Pathol 36, 610-612
Adams MJ (1991) The distribution of barley yellow mosaic virus (BaYMV) and barley mild mosaic virus (BaMMV) in UK winter barley samples, 1987-1990. Plant Pathol 40, 53-58

Adams MJ, Jones DR, O'Neill TM, Hill SA (1993) The effect of cereal break crops on barley mild mosaic virus. Ann Appl Biol 123, 37-45

Bendiek J, Davidson AD, Schulze SC, Schell J, Steinbiss HH (1993) Identification and classification of a resistance breaking strain of barley yellow mosaic virus. Ann Appl Biol 122, 481-491

Friedt W (1983) Mechanical transmission of soil-borne barley yellow mosaic virus. Phytopath $Z 106,16-22$

Froidmont F, Maroquin C, Steyer S (1993) La sélection d'orges résistantes à la mosaïque. Parasitica 49 , 107-114

Götz R, Friedt W (1993) Resistance to the barley yellow mosaic virus complex-differential genotypic reactions and genetics of BaMMV-resistance of barley (Hordeum vulgare L). Plant Breed 111, 125131

Huth W (1989) Management of yellow mosaic inducing viruses on barley by selection. EPPO Bull 19, 547553

Kaiser R, Friedt W (1992) Gene for resistance to barley mild mosaic virus in German winter barley located on chromosome 3L. Plant Breed 108, 169-172

Kashiwazaki S, Hayano Y, Minobe Y, Omura T, Hibino $H$, Tsuchizaki T (1989) Nucleotide sequence of the capsid protein of barley yellow mosaic virus. $J$ Gen Virol 70, 3015-3023

Peerenboom E, Pröls M, Schell J, Steinbiss HH, Davidson AD (1992) The complete nucleotide sequence of RNA1 of a German isolate of barley yellow mosaic virus and its comparison with a Japanese isolate. J Gen Virol 73, 1303-1308 